\title{
Research.
}

\section{THE INFLUENCE OF TRADE UNIONS, COLLECTIVE LABOR AGREEMENTS AND INDUSTRIAL RELATIONS ON THE WELFARE OF WORKERS AT PT. UNIPLASTINDO INTERBUANA}

\author{
Dadang Heri Kusumah ${ }^{1)^{*}}$;Tri Wahyu Wirjawan ${ }^{2)}$; Nurmubin \\ Dalidjo3) \\ Department of Management, Pelita Bangsa University \\ dadangherikusumah3@gmail.com¹), triwahyuwiryawan@gmail.com²), nurmubindalidjo@yahoo.com ${ }^{3)}$ \\ ${ }^{*}$ Corresponding author
}

Received: December 26, 2021 Accepted: December 30, 2021 Published: December 31, 2021

To cite this article: Kusumah, DH; Wirjawan, TH; Dalidjo, N (2021). The influence of trade unions, collective labor agreements and industrial relations on the welfare of workers at PT.Uniplastindo Interbuana. The Management Journal Of Binaniaga, 6 (2), 215-228 . doi:10.33062/mjb.v6i2.478

\begin{abstract}
The background of this research is to find out whether trade unions, collective labor agreements, and industrial relations have an effect on workers' welfare.In this research, data were collected using questionnaires as research data from 60 respondents from a total population of 144 workers who are members of trade unions at PT. Uniplastindo Interbuana. Hypothesis testing conducted using the SPSS version 22 application partially with the comparison method of the $t_{\text {count }}$ value with the table value resulted in the conclusion that Variable $\mathrm{X} 1$, ( $\mathrm{t}_{\text {count }} 3.539>$ table 1.673) then $\mathrm{H} 1$ or the first hypothesis was accepted. Variable $\mathrm{X} 2$, ( $\mathrm{t}_{\text {count }} 3.057>$ $\left.t_{\text {table }} 1.673\right)$ then $\mathrm{H} 2$ or the second hypothesis is accepted. Variable X3, ( $\mathrm{t}_{\text {count }} 2.864$ $>t_{\text {table }}$ 1.673) then $\mathrm{H} 3$ or the third hypothesis is accepted.
\end{abstract}

Keywords: Labor Union, Collective Labor Agreement, Industrial Relations and Workers Welfare

\section{INTRODUCTION}

\section{Background}

Employment problems that still often occur in a company are related to the working relationship of both parties between the worker and the employer, apart from the issue of rights, it is a matter of interest. One of the most fundamental issues related to issues of rights and interests is the issue of worker welfare.

The workers welfare is not only related to a number of normative matters that have been regulated and stipulated in a rule or law made by the government, but also to several matters of an interest nature whose legal basis is only a collective agreement resulting from negotiations.

On the other hand, workers personally also do not have bargaining or a strong bargaining value to get welfare from the employers because personally not all workers have the opportunity and capacity to represent other workers in the negotiation process that determines company policies.

The measure of welfare for formal workers and non-formal workers, both those who work in the company or those who work outside the company, is always identical to the nominal value of income or wages every month.

The income or wages received by workers, especially those who work in the company every month generally consist of three (3) components, basic salary, fixed allowances and non-fixed allowances which as a whole refer to things that are normative and of interest. For the amount of basic salary in general, the

Dadang Heri Kusumah; Tri Wahyu Wirjawan; and Nurmubin Dalidjo. The influence of trade unions, collective labor agreements and industrial relations on the welfare of workers at 
company usually sets a policy by referring to the decree from the Head of the Governor of each province regarding the amount of increase in the Provincial Minimum Wage, Regency/City Minimum Wage and District/City Sectoral Minimum Wage every year.

For workers' welfare which is normative, of course, it is not too problematic for most workers as a whole or from the company itself considering that normative matters such as salary/basic wages or minimum wages and sectoral minimum wages for several areas have been regulated in the laws and regulations that has been set by the government so that basically the company just needs to run the rules. Meanwhile, for welfare that is outside the normative nature, the government does not regulate it clearly so that sometimes there are some companies that do not want to provide it on the grounds that they have implemented the rules and obligations in accordance with government regulations which eventually trigger disputes from both parties.

\section{LITERATURE REVIEW}

\section{Workers' Welfare}

The welfare of workers/laborers is one of the goals to be achieved in the business world, be it entrepreneurs, workers themselves or government agencies whose main task is to manage human resources and other parties from private institutions. Welfare is the main goal regardless of any system and technology used in the production process. One aspect of human welfare is occupational safety and health, especially in the era of industrialization. Workers whose welfare is poor, not only causes discouragement but their productivity will decrease. Furthermore, they are not interested, apathetic in doing their work and their loyalty to the company will be reduced as well. Choudhary (2017) states that the welfare of workers is one of the important aspects of the industrial world in the company. Workers' welfare functions as steps in implementing social security, which contribute to improving the situation and conditions of social security for workers/laborers where workers/laborers are employed. Employee welfare facilities in the company affect the behavior of workers and the productivity of the company.

Indicators of the level of welfare of workers according to Manullang (2009) quoted in Chandra (2017) said that indicators of the level of welfare of workers are income for one month, satisfaction with income, monthly consumption/expenditure, perception of salary adequacy to meet the needs of life, health and safety. work, utilization and response to other welfare (mess and means of transportation in the form of shuttle buses), religious life, ease of doing sports, social status, feeling at home while working at the company, feeling safe from criminal disturbances at work and around the workplace.

From the description of these indicators, it can be concluded in more detail that the indicators of worker welfare are as follows:

1. Wages

2. Fixed allowances

3. Variable allowances

4. Worship facilities

5. Recreation

6. Social Security

7. Organizing

According to the theory of worker welfare put forward by experts, it can be concluded that worker welfare is a fulfilment or achievement of the physical and spiritual needs of workers both within the company and outside the company which can directly or indirectly affect and increase work productivity in a safe work

Dadang Heri Kusumah; Tri Wahyu Wirjawan; and Nurmubin Dalidjo. The influence of trade unions, collective labor agreements and industrial relations on the welfare of workers at 
environment. safe and healthy. Welfare is also one of the efforts of company leaders to stimulate and increase the morale of the workers or workers, so that worker productivity also increases and the goals of a company can be achieved.

\section{Labor Union}

In the general provisions of Article 1 of the Manpower Law Number 13 of 2003 quoted by Siswati (2017), it is stated that a trade union/labor union is an organization formed from, by, and for workers both inside and outside the company, which is free and open, independent, democratic, and responsible for:

1. Defend the rights and interests of workers.

2. Protect the rights of workers' interests.

3. Fight for the rights and interests of workers.

4. Improving the welfare of workers and their families.

Mohamad Nor et.al (2018) states that trade unions are associations or combinations of workers or employers, as workers whose workplace is in Peninsular Malaysia, Sabah or Sarawak, depending on the situation, or employers who employ workers in Peninsular Malaysia, Sabah or Sarawak. Trade/labor unions need to be recognized by the government authority or the competent authority that regulates manpower before they can be involved in the collective bargaining process on behalf of workers to deal with employers, the negotiation process between employers and their workers regarding disputes regarding wages, hours of work, working conditions, and other terms of employment.

From the results of previous studies, as stated by Arthawati (2018), it shows that trade unions greatly affect the welfare of workers in a company and provide benefits for them in fulfilling their daily needs. Thus, the role of trade unions is very significant in increasing the welfare of workers.

\section{Collective Labor Agreement}

According to Law no. 13 of 2003 concerning Manpower as quoted by Aninditiya et.al (2015) states that trade unions have the right to make collective labor agreements to express their aspirations. The contents of the collective labor agreement made by the employer and the trade union usually contain matters relating to:

1. The rights of workers or laborers.

2. Obligations of workers or laborers.

3. The rights of trade unions/labor unions.

4. Obligations of trade unions/labor unions.

5. Entrepreneur's rights.

6. Obligations of entrepreneurs.

Saim Aşçı (2016) states that a collective labor agreement is a written contract or written agreement between the workers represented by the trade union and the entrepreneur represented by the Board of Directors and/or the Management who is placed to regulate all provisions at the conclusion, content and expiration of the employment contract. between a trade union and a trade union or entrepreneur who is not a member of a trade union and may also include the rights and obligations of both parties, the reciprocity of each party, the application and supervision of agreements and the means to be used for dispute resolution.

Collective labor agreement in terms of legal knowledge is a private agreement. One of the principles of private law is the freedom of both parties to make agreements. The result of the collective work agreement is in accordance with the agreement that regulates the fulfilment of the rights and obligations of workers, the fulfilment of the rights and obligations of trade unions and the fulfilment of the rights and obligations of the entrepreneur. From the results of the

Dadang Heri Kusumah; Tri Wahyu Wirjawan; and Nurmubin Dalidjo. The influence of trade unions, collective labor agreements and industrial relations on the welfare of workers at 
agreement contained in the collective work agreement, the entrepreneur and the trade union or worker can properly implement and realize their rights and obligations so that harmonious industrial relations can be created between the entrepreneur and the trade union and/or with the workers in the company.

\section{Industrial Relation}

Zulkarnaen (2016) states that Industrial Relations is a relationship that creates work tranquility and business peace or industrial peace, or a dynamic condition in working relationships in companies where there are three important elements:

1. The rights and obligations of both parties are guaranteed to be implemented.

2. Disputes that occur can be resolved internally.

3. Strikes and company closures (lock-out) as the bargaining value of each party do not need to be used to impose their will.

4. Disputes that have occurred have been properly resolved through bipartite and tripartite cooperation institutions.

Zulkarnaen (2016) states that the ultimate goal of the industrial relations system is welfare for all parties. The employers get an increase in the productivity of their workers and for workers/laborers get an increase in welfare, and this increase must be done continuously from time to time. All parties who are directly or indirectly involved in the industrial relations system are obliged to cooperate with one another by carrying out their respective functions and duties to seek to increase company productivity and the welfare of workers/labourers, in order to realize national economic development goals in accordance with the aim of the 1945 Constitution, to achieve general welfare.

\section{Initial Research Hypothesis}

The hypothesis according to Sugiyono (2005:51) is a temporary answer to the research problem formulation. The initial hypotheses of this research are:

1. First Hypothesis

In accordance with research conducted by Endang Siswati in an article entitled The Influence of Labor Unions on Work Productivity of Production Workers in East Java, which was published in the Journal of Management and Accounting Science Vol 5 number: 2 in December 2017 (59) resulted in the conclusion that trade unions have a positive effect and significantly to the performance of workers, the welfare of workers will also be higher.

2. Second Hypothesis

Allegedly according to research conducted by Rahadian Dimas Aninditiya, Arik Prasetya, and Yuniadi Mayowan in their article entitled The Effect of Work Agreements and Collective Labor Agreements on Employee Rights and Job Satisfaction published in the Journal of Business Administration Vol. 28 No. November 1, 2015 resulted in the conclusion that there is a significant relationship between collective labor agreements and workers' welfare because of the benefits and roles of collective labor agreements that are made, negotiated and stipulated jointly between employers and trade unions, namely to create harmonious industrial relations and between the employers and the workers in order to channel the aspirations of the members of the trade unions and to fight for the welfare of the workers.

3. Third Hypothesis

Allegedly according to research conducted by Ahmad Hunaeni Zulkarnaen in his article entitled "Vulnerable Problems in Industrial Relations and the Concept of the Indonesian Welfare State" which was published in the Justitia Pulpit journal Volume II No. 02 July-December 2016 Edition concludes that

Dadang Heri Kusumah; Tri Wahyu Wirjawan; and Nurmubin Dalidjo. The influence of trade unions, collective labor agreements and industrial relations on the welfare of workers at 
there is a significant influence between industrial relations and workers' welfare because basically industrial relations are created and created by workers/labourers, employers and the government in essence, apart from aiming to provide legal protection to workers/laborers, as well as to realizing prosperity for all Indonesian people.

\section{RESEARCH METHOD}

In writing this scientific paper, the research method used is quantitative research methods. Quantitative research method is a research method Accoeding to the philosophy of positivism, used to research on a particular population or sample. The population in this research were all workers who are members of a trade union at PT. Uniplastindo Interbuana. The population in this research is in accordance with the number of workers who are members of the Trade Union as many as 144 members using the Slovin Formula with e of $10 \%$ so that the total sample in this research is 60 respondents. The research design in scientific writing of the variables of the influence of trade unions, collective labor agreements, industrial relations on the welfare of workers at PT. Uniplastindo Interbuana can be seen in the description of the image as follows:

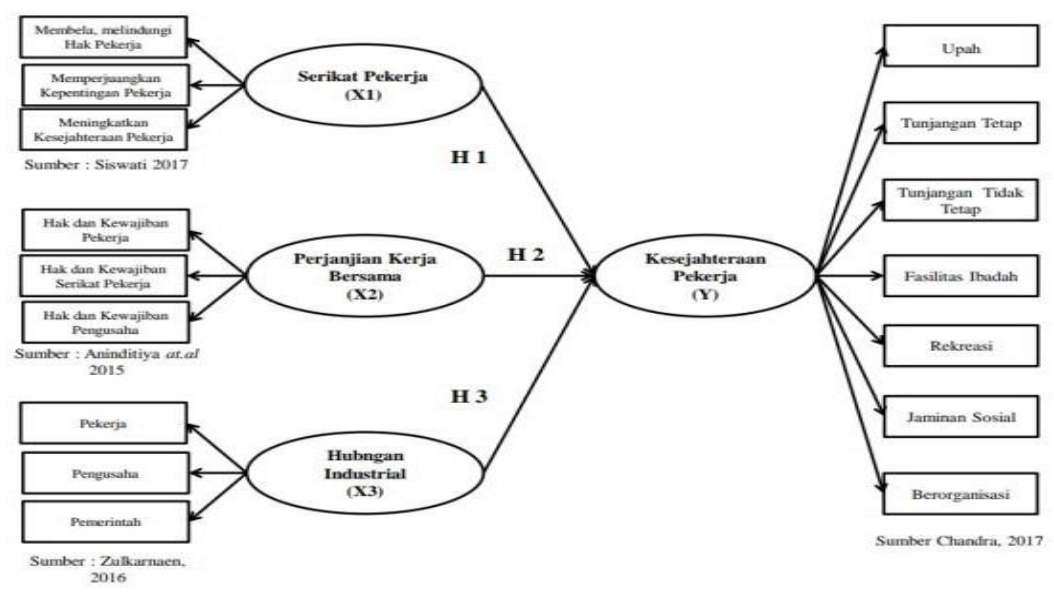

Source: Researcher, 2019

\section{RESEARCH RESULTS AND DISCUSSION}

\section{Research Results}

The results of research conducted on labor union variables, collective labor agreement variables, industrial relations variables (independent variable or variable $\mathrm{X}$ ) and worker welfare variables (dependent variable or variable $\mathrm{Y}$ ) will be discussed with the results of data processing as follows:

\section{Validity Test}

Variable X1

\begin{tabular}{l|l|l|l}
\hline Questionnaire & rcount & r table & Remarks
\end{tabular}

Dadang Heri Kusumah; Tri Wahyu Wirjawan; and Nurmubin Dalidjo. The influence of trade unions, collective labor agreements and industrial relations on the welfare of workers at PT.Uniplastindo Interbuana 
The Management Journal of BINANIAGA Vol. 06, No.02, December 2021 p-ISSN: 2527 - 4317, e-ISSN: $2580-149 x$

$6^{\text {th }}$ Accreditation Rating: April 04, 2019 - April 03, 2024

\begin{tabular}{|c|c|c|c|}
\hline P1 & 0.486 & 0.266 & Valid \\
\hline P2 & 0.523 & 0.266 & Valid \\
\hline P3 & 0.546 & 0.266 & Valid \\
\hline P4 & 0.560 & 0.266 & Valid \\
\hline P5 & 0.570 & 0.266 & Valid \\
\hline P6 & 0.707 & 0.266 & Valid \\
\hline P7 & 0.822 & 0.266 & Valid \\
\hline P8 & 0.853 & 0.266 & Valid \\
\hline P9 & 0.637 & 0.266 & Valid \\
\hline P10 & 0.607 & 0.266 & Valid \\
\hline P11 & 0.764 & 0.266 & Valid \\
\hline P12 & 0.657 & 0.266 & Valid \\
\hline
\end{tabular}

Variable $\mathrm{X} 2$

\begin{tabular}{|c|c|c|c|}
\hline Questionnaire & r count & r table & Remarks \\
\hline P1 & 0.739 & $0,1.266$ & Valid \\
\hline P2 & 0.766 & 0.266 & Valid \\
\hline P3 & 0.566 & 0.266 & Valid \\
\hline P4 & 0.754 & 0.266 & Valid \\
\hline P5 & 0.791 & 0.266 & Valid \\
\hline P6 & 0.694 & 0.266 & Valid \\
\hline P7 & 0.698 & 0.266 & Valid \\
\hline P8 & 0.862 & 0.266 & Valid \\
\hline P9 & 0.696 & 0.266 & Valid \\
\hline P10 & 0.762 & 0.266 & Valid \\
\hline P11 & 0.747 & 0.266 & Valid \\
\hline P12 & 0.750 & 0.266 & Valid \\
\hline
\end{tabular}

Variable X3

\begin{tabular}{|c|c|c|c|}
\hline Questionnaire & r count & r table & Remarks \\
\hline P1 & 0.802 & 0.266 & Valid \\
\hline P2 & 0.833 & 0.266 & Valid \\
\hline P3 & 0.756 & 0.266 & Valid \\
\hline P4 & 0.462 & 0.266 & Valid \\
\hline P5 & 0.440 & 0.266 & Valid \\
\hline P6 & 0.708 & 0.266 & Valid \\
\hline P7 & 0.802 & 0.266 & Valid \\
\hline P8 & 0.542 & 0.266 & Valid \\
\hline P9 & 0.537 & 0.266 & Valid \\
\hline P10 & 0.504 & 0.266 & Valid \\
\hline P11 & 0.313 & 0.266 & Valid \\
\hline
\end{tabular}

Dadang Heri Kusumah; Tri Wahyu Wirjawan; and Nurmubin Dalidjo. The influence of trade unions, collective labor agreements and industrial relations on the welfare of workers at 


\begin{tabular}{|l|l|l|l|}
\hline P12 & 0.358 & 0.266 & Valid \\
\hline
\end{tabular}

Variable $Y$

\begin{tabular}{|c|c|c|c|}
\hline Questionnaire & r count & r table & Remarks \\
\hline P1 & 0.755 & 0.266 & Valid \\
\hline P2 & 0.683 & 0.266 & Valid \\
\hline P3 & 0.811 & 0.266 & Valid \\
\hline P4 & 0.652 & 0.266 & Valid \\
\hline P5 & 0.757 & 0.266 & Valid \\
\hline P6 & 0.931 & 0.266 & Valid \\
\hline P7 & 0.881 & 0.266 & Valid \\
\hline P8 & 0.857 & 0.266 & Valid \\
\hline P9 & 0.644 & 0.266 & Valid \\
\hline P10 & 0.870 & 0.266 & Valid \\
\hline P11 & 0.863 & 0.266 & Valid \\
\hline P12 & 0.782 & 0.266 & Valid \\
\hline
\end{tabular}

According to the results of the validity test of each of the variables above, it can be seen that 12 instrument items from each variable from a total of four (4) variables can be declared valid, because $r_{\text {count }}>r_{\text {table }}$ so that the statement can be used in research.

\section{Reliability Test}

\begin{tabular}{|ccc|} 
Variabel & $\begin{array}{c}\text { Croncbach's } \\
\text { Alpha }\end{array}$ & N of Items \\
\hline X1 & 0.870 & 12 \\
\hline X2 & 0.921 & 12 \\
X3 & 0.826 & 12 \\
\hline Y & 0.944 & 12 \\
\hline
\end{tabular}

The reliability test of each variable is known that each variable out of a total of four (4) variables is declared reliable because each of the Cronbach Alpha value variables in total shows a number or value greater than the Cronbach Alpha value of 0.60 .

Normality Test

Kolmogorov Smirnov Test Results

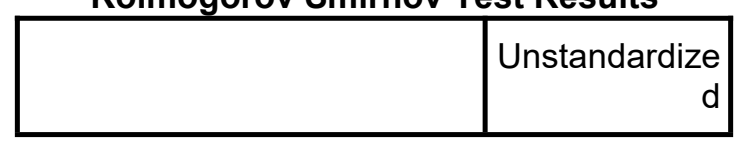

Dadang Heri Kusumah; Tri Wahyu Wirjawan; and Nurmubin Dalidjo. The influence of trade unions, collective labor agreements and industrial relations on the welfare of workers at PT.Uniplastindo Interbuana 
The Management Journal of BINANIAGA Vol. 06, No.02, December 2021 p-ISSN: 2527 - 4317, e-ISSN: $2580-149 x$

$6^{\text {th }}$ Accreditation Rating: April 04, $2019-$ April 03, 2024

\begin{tabular}{|l|l|r|}
\hline \multicolumn{2}{|l|}{} & Residual \\
\hline $\mathrm{N}$ & 35 \\
\hline Normal & Mean & .0000000 \\
$\begin{array}{l}\text { Parameters } \\
\mathrm{b},\end{array}$ & Std. Deviation & 1.11876091 \\
Most & & \\
Extreme & Absolute & .105 \\
Differences & Positive & .105 \\
\cline { 2 - 2 } & Negative & -.105 \\
& & .105 \\
Statistic Test & .200 c,d \\
\hline \multicolumn{2}{|l|}{ Asymp. Sig. (2-tailed) } \\
\hline
\end{tabular}

Asymp Significance Value. Sig. (2-tailed) of 0.200 is greater than the probability value of $0.05(0.200>0.05)$. It can be concluded that the data is normally distributed so that the assumption of normality in the regression model is met.

\section{Multicollinearity Test}

\begin{tabular}{c|c|c|c|}
\multicolumn{2}{|c|}{ Model } & \multicolumn{2}{c|}{ Collinearity Statics } \\
\hline \multirow{1}{*}{1} & Constant & Tolerance & VIF \\
\hline \multirow{1}{*}{ SP $(X 1)$} & .498 & 2.010 \\
\hline PKB $(X 2)$ & .428 & 2.334 \\
\hline HI (X3) & .506 & 1.978 \\
\hline
\end{tabular}

The Tolerance value for the Labor Union Variable (X1) is 0.498 for the Collective Labor Agreement Variable (X2) is 0.428 and for the Industrial Relations Variable (X3) is 0.506 . Of the 3 independent variables above, the tolerance value is greater than 0.10 so it can be concluded that there is no symptom of multicollinearity in this regression model.

The value of Variance Inflating Factor (VIF) for Labor Union Variable (X1) is 2.010, for Collective Labor Agreement Variable (X2) is 2.334 and for Industrial Relations Variable (X3) is 1.978. From the 3 independent variables above, the value of Variance Inflating Factor (VIF) is less than 10.00 , so it can be concluded that there are no symptoms of multicollinearity in this regression model.

\section{Heteroscedasticity Test}

\begin{tabular}{|c|c|c|c|}
\hline \multicolumn{2}{|c|}{ Model } & \multicolumn{2}{|c|}{ Collinearity Statics } \\
\hline & Constant & Tolerance & Sig \\
\hline \multirow{3}{*}{1} & (Constant) & 1.520 & .134 \\
\hline & $\mathrm{SP}(\mathrm{X} 1)$ & 1.071 & .289 \\
\hline & PKB (X2) & -2.942 & .005 \\
\hline
\end{tabular}

The significance value for the labor union variable (X1) is 0.289 , for the collective labor agreement variable (X2) is 0.005 and for the industrial relations variable (X3) is 0.956 .

Of the 3 independent variables mentioned above, each significance value of each independent variable (variable $X$ ) is above and equal to the probability value of 0.05 so that it can be concluded that there are no symptoms of heteroscedasticity from the 3 independent variables (variable $\mathrm{X}$ ) above.

Dadang Heri Kusumah; Tri Wahyu Wirjawan; and Nurmubin Dalidjo. The influence of trade unions, collective labor agreements and industrial relations on the welfare of workers at 


\section{Multiple Regression Test}

\begin{tabular}{|c|c|c|c|c|}
\hline Model & $\mathrm{R}$ & RSquare & $\begin{array}{c}\text { Adjusted R } \\
\text { Square }\end{array}$ & Durbin- Watson \\
\hline 1 &. $\mathbf{8 4 9}$ & $\mathbf{. 7 2 1}$ & .706 & 1.402 \\
\hline
\end{tabular}

The coefficient of determination is the contribution or influence of each independent variable (union variable, collective labor agreement variable and industrial relations variable or variable $\mathrm{X}$ ) on the dependent variable of the worker welfare variable (variable Y).

\section{Partial Multiple Regression Test}

\begin{tabular}{|c|c|c|c|c|c|}
\hline & \multirow[t]{2}{*}{ Model } & \multicolumn{2}{|c|}{$\begin{array}{c}\text { Unstandardized } \\
\text { Coefficients }\end{array}$} & \multirow[t]{2}{*}{$\mathrm{t}$} & \multirow[t]{2}{*}{ Sig. } \\
\hline & & B & $\begin{array}{c}\text { S. } \\
\text { Error }\end{array}$ & & \\
\hline \multirow{4}{*}{1} & (Constant) & -26.341 & 7.949 & -3.314 & .002 \\
\hline & $\mathrm{SP}(\mathrm{X} 1)$ & .608 & .172 & 3.539 & .001 \\
\hline & $\mathrm{PKB}(\mathrm{X} 2)$ & .365 & .119 & 3.057 & .003 \\
\hline & $\mathrm{HI}(\mathrm{X} 3)$ & .466 & .163 & 2.864 & .006 \\
\hline
\end{tabular}

The results of the $t_{\text {count }}$ value and the significance value of each $X$ variable and the regression equation of the effect of the $X$ variable on the $Y$ variable. The formula for the regression equation in multiple regression analysis in this research is as follows:

$\mathrm{Y}=\mathrm{a}+\mathrm{b} 1 \mathrm{X} 1+\mathrm{b} 2 \mathrm{X} 2+\mathrm{b} 3 \mathrm{X} 3$

$Y=-26,341+0,608+0,365+0,466$

\section{Hypothesis Test}

The hypothesis test to determine whether the hypothesis is accepted or rejected is the influence of variable $X$ on variable $Y$ is to use the basis of comparison of the value of $t_{\text {count }}$ with the value of table where the basis for making decisions is as follows:

If the value of $t_{\text {count }}$ is greater than the value of table (tcount $>t_{\text {table }}$ ) then there is the influence of the independent variable or independent variable $(X)$ on the dependent variable or dependent variable $(\mathrm{Y})$.

a. If the value of $t_{\text {count }}$ is less than the value of $t_{\text {table }}\left(t_{\text {count }}<t_{\text {table }}\right)$ then there is no effect of the independent variable or independent variable $(X)$ on the dependent variable or dependent variable $(\mathrm{Y})$.

From the multiple regression analysis test, it is known that:
a. The value of $t_{\text {count }}(\mathrm{X} 1) \quad: 3.539$
b. The value of $t_{\text {count }}(\mathrm{X} 2) \quad: 3.057$
c. The value of $t_{\text {count }}(\mathrm{X} 3) \quad: 2.864$

So that it can be concluded that the hypothesis testing to be conducted in this research using the method of comparing the $t_{\text {count }}$ value with the $t_{\text {table }}$ value of each research variable in each hypothesis decision making can be decided as follows:

1. H1 : First Hypothesis Test. According to the method of comparing the $t_{\text {count }}$ value with the $t_{\text {table }}$ value, the first hypothesis is accepted because the $t_{\text {count }}$ value of the $\mathrm{X} 1$ variable is 3.539 which is greater than the $t_{\text {table }}$ value of 1.673 ( $\mathrm{t}_{\text {count }} 3.539>$

Dadang Heri Kusumah; Tri Wahyu Wirjawan; and Nurmubin Dalidjo. The influence of trade unions, collective labor agreements and industrial relations on the welfare of workers at PT.Uniplastindo Interbuana 
table 1.673). So the conclusion is that there is a significant effect between the variable union $(\mathrm{X} 1)$ on the variable of worker welfare $(\mathrm{Y})$

2. H2 : Second Hypothesis Test. The conclusion is that there is a significant effect between the collective labor agreement variable $(\mathrm{X} 2)$ on the worker welfare variable $(\mathrm{Y})$.

3. H3 : Third Hypothesis Test. According to the method of comparing the value of $t_{\text {count }}$ with $t_{\text {table, }}$ the third hypothesis is accepted because the $t_{\text {count }}$ value of the $X 3$ variable is 2.864 which is greater than the $t_{\text {table }}$ value of $1.673\left(t_{\text {count }} 2.864>t_{\text {table }}\right.$ 1.673). So the conclusion is that there is a significant effect between the industrial relations variable $(\mathrm{X} 3)$ on the worker welfare variable $(\mathrm{Y})$.

\section{Coefficient of Determination Test}

The value of $\mathrm{R}$ Square 0.721 indicates that there is a relationship between the variable union (X1), collective labor agreement $(X 2)$ and industrial relations variable (X3) on the worker welfare variable $(Y)$. The value of $R$ square produces a value of 0.721 . So if it is formed in the form of a percentage, it will get a percentage value of $72.1 \%$. So from the results of the table it can be concluded that the remaining percentage contribution value of $27.9 \%(100-72.1=27.9)$ is influenced by other factors other than the trade union variable $(\mathrm{X} 1)$, the collective labor agreement variable ( $\mathrm{X} 2$ ) and industrial relations variables (X3) were studied.

From the overall $R$ Square value of the $X$ variable of 0.721 or $72.1 \%$ it can be calculated the effective contribution (SE) and the relative contribution (SR) of the labor union variable $(\mathrm{X} 1)$, the collective labor agreement variable $(\mathrm{X} 2)$ and the industrial relations variable $(\mathrm{X} 3)$ on the variable of worker welfare (variable $\mathrm{Y}$ ).

From the results of the correlation analysis that has been conducted on the overall validity test, it can be seen in the following table:

\section{Pearson Correlatiaon}

\begin{tabular}{|c|c|}
\hline Variabel X & $\begin{array}{c}\text { Koeffisien } \\
\text { Korelasi }\end{array}$ \\
\hline Serikat Pekerja (X1) & 0,750 \\
\hline Perjanjian Kerja Bersama (X2) & 0,762 \\
\hline Hubungan Industrial (X3) & 0,720 \\
\hline
\end{tabular}

The Effective Contribution (SE) and Relative Contribution (SR) of each variable $X$ to variable $Y$ can be described as follows:

a. Effective Contribution Formula (SE)SE(X)\% $=$ Betax.$r_{x y} .100 \%$

1. SE $\times 1 \%$

Beta X1.rxy.100\%0,354. 0,750.100\%

$26,55 \%$

2. SE $\times 2 \%$

Beta X2.rxy.100\%0,329. 0,762.100\%

$25,07 \%$

3. SE $\times 3 \%$

Beta X1.rxy.100\%0,284. 0,720.100\%

$20,45 \%$

Dadang Heri Kusumah; Tri Wahyu Wirjawan; and Nurmubin Dalidjo. The influence of trade unions, collective labor agreements and industrial relations on the welfare of workers at 


\section{SE Total $=\mathbf{7 2 , 0 7} \%=\mathbf{7 2 , 1} \%$}

The effective contribution (SE) from the independent variable $(X)$ to the dependent variable $(Y)$ which has the greatest influence is the trade union variable (X1) with an effective contribution value of $26.55 \%$. For the total value of the effective contribution (SE) as a whole is $72.1 \%$ or equal to the value of the coefficient of determination or $\mathrm{R}$ square of $72.1 \%$.

\section{b. Relative Contribution Formula (SR) $S R(X) \%=$ Effective Contribution \%}

\section{RSquare}

1. $S R X 1 \%$ SE $(X 1) \% / R 226,55 \% / 72,1 \% 0,368=36,8 \%$

2. $S R X 2 \%$ SE $(X 2) \% / R 225,07 \% / 72,1 \% 0,348=34,8 \%$

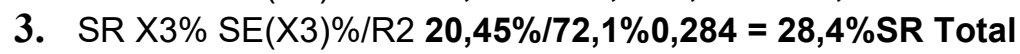

$36,8 \%+34,8 \%+28,4 \%$

$100 \%$

From the above calculation, it can be concluded that the relative contribution $(\mathrm{SR})$ of the trade union variable $(\mathrm{X} 1)$ to the worker welfare variable $(\mathrm{Y})$ is $36.8 \%$, the collective labor agreement variable $(\mathrm{X} 2)$ to the worker welfare variable $(\mathrm{Y})$ is $34.8 \%$. and the industrial relations variable $(\mathrm{X} 3)$ to the worker welfare variable $(\mathrm{Y})$ of $28.4 \%$. Overall the total relative contribution (SR) is $100 \%$ or 1 .

\section{Discussion}

The validity test is conducted by comparing between $r$ arithmetic and $r_{\text {table, }}$ while to get $r_{\text {table }}$ it is done by using $r$ product moment table, which is to determine alpha $=0.05$ then $n$ (sample) $=60$ people so that the rable value is 0.266 . Accoeding to the results of the validity test above, it can be seen that all statement instruments in the variables of trade unions, collective labor agreements, and industrial relations produce $r_{\text {count }}$ above 0.266 so that 48 statements in this questionnaire can be said to be valid and can be used as statements in research.

From all the reliability tables above, it can be seen that all statement instruments in the trade union variable (X1) Cronbach's Alpha value of 0.870 , collective labor agreement (X2) Cronbach's Alpha value of 0.921 , industrial relations (X3) Cronbach's Alpha value of 0.826 and worker welfare $(Y)$ Cronbach's Alpha value is 0.944 . Of the four variables above, all variables have Cronbach's Alpha values above 0.60 . This shows that all statements can be declared reliable, and can be used for data collection in measuring the variables of trade unions, collective labor agreements, industrial relations and worker welfare.

\section{Data Analysis}

1. According to all the tests that have been conducted above regarding the influence of trade unions on workers' welfare, the effective contribution value (SE) is $26.55 \%$. This shows that there is a direct influence between the trade union variable $(\mathrm{X} 1)$ on the worker welfare variable $(\mathrm{Y})$. From the test results on the $t$-test, the $t_{\text {count }}$ value is 3.539 with a significance level of 0.001 which means the $t_{\text {count }}>t_{\text {table }}$ and sig $<0.05$. This means that the hypothesis proposed by the author is accepted, namely that there is a positive and significant influence between the trade union variables on the welfare of workers at PT. Uniplastindo Interbuana.

2. According to all the tests that have been conducted above regarding the effect of the collective labor agreement on the welfare of workers, the effective contribution value (SE) is $25.07 \%$. This shows that there is a direct influence between the collective labor agreement variable $(\mathrm{X} 2)$ on the worker welfare variable $(\mathrm{Y})$. From the test results on the $\mathrm{t}$-test, the $\mathrm{t}$-count value is 3.057 with a significance level of 0.003 which means the t-count $>t_{\text {table }}$ and the sig value

Dadang Heri Kusumah; Tri Wahyu Wirjawan; and Nurmubin Dalidjo. The influence of trade unions, collective labor agreements and industrial relations on the welfare of workers at 
$<0.05$. This means that the hypothesis proposed by the author is accepted, namely that there is a positive and significant influence between the variables of the collective bargaining agreement on the welfare of workers at PT. Uniplastindo Interbuana.

3. According to all the tests that have been conducted above regarding the effect of industrial relations on the welfare of workers, the effective contribution value (SE) is $20.45 \%$. This shows that there is a direct influence between the industrial relations variable $(\mathrm{X} 3)$ on the worker welfare variable $(\mathrm{Y})$. From the test results on the $\mathrm{t}$-test, the $\mathrm{t}_{\text {count }}$ value is 2.864 with a significance level of 0.006 , which means the $t_{\text {count }}>$ ttable and the sig value $<0.05$. This means that the hypothesis proposed by the author is accepted, namely that there is a positive and significant influence between industrial relations variables on the welfare of workers at PT. Uniplastindo Interbuana.

\section{CONCLUSIONS AND SUGGESTIONS}

\section{Conclusion}

According to the analysis and discussion above and the purpose of this research, namely to determine the effect of trade unions, collective labor agreements and industrial relations on workers' welfare with a case research at PT. Uniplastindo Interbuana with the following conclusions:

1. Trade Unions show an influence of $26.55 \%$ on the welfare of workers. From the results of the hypothesis test, the $t_{\text {count }}$ value is 3.539 with a significance level of 0.001 . Then $t_{c o u n t}$ is greater than table $(3.539>1.673)$ and the significance value is less than $0.05(0.001<0.05)$. It can be concluded that through research and scientific writing, it is proven that there is an influence of trade unions on the welfare of workers at PT. Uniplastindo Interbuana in accordance with the results of the hypothesis test proposed by the author.

2. Collective Labor Agreements show an effect of $25.07 \%$ on the welfare of workers. The results of the hypothesis test show the $t_{\text {count }}$ value of 3.057 with a significance level of 0.003 . Then $t_{\text {count }}$ is greater than table $(3.057>1.673)$ and the significance value is less than $0.05(0.003<0.05)$. It can be concluded that through research and scientific writing it is proven that there is an effect of collective labor agreements on the welfare of workers at PT. Uniplastindo Interbuana is in accordance with the results of the hypothesis test that has been proposed by the author.

3. Industrial Relations shows an effect of $20.45 \%$ on the welfare of workers. The results of the hypothesis test show the $t_{\text {count }}$ value of 2.864 with a significance level of 0.006 . Then $t_{\text {count }}$ is greater than table $(2.864>1.673)$ and the significance value is less than $0.05(0.006<0.05)$. It can be concluded that through research and scientific writing it is proven that there is an influence of industrial relations on the welfare of workers at PT. Uniplastindo Interbuana is in accordance with the results of the hypothesis test that has been proposed by the author.

\section{Suggestions}

1. The welfare of workers does not always depend on the rules of the laws made by the government or on the policies of the owners of the company.l

2. Welfare can be determined jointly by workers and employers through the means of industrial relations between employers and workers represented by trade

Dadang Heri Kusumah; Tri Wahyu Wirjawan; and Nurmubin Dalidjo. The influence of trade unions, collective labor agreements and industrial relations on the welfare of workers at 
unions.

3. Therefore, for readers, especially those who still have the status of a worker who is still receiving wages, there is no harm in learning about the meaning of industrial relations, the scope of collective labor agreements and the functions and roles of trade unions. So that the main goal of the workers in order to improve the welfare of the workers is not completely dependent on other parties. However, workers can also be directly involved in determining, fighting for and improving the welfare of workers together.

\section{REFERENCES}

Adeniji dan Moses Adenuga (2015) An Analysis of Industrial RelationsPractice in Nigeria and Ghana (Similarities and Differences in their Systems).Jurnal GlobalJournal of Researches in Engineering: $G$ Volume 15Version 1.0

Ahmad Hunaeni Zulkarnaen (2016) Masalah Rawan Dalam Hubungan Industrial Dan Konsep NegaraKesejahteraan Indonesia. Jurnal Mimbar Justitia Vol. II No. 02Edisi Juli-Desember

Endang Siswati (2017) Pengaruh Serikat Buruh Terhadap ProduktivitasKerja Buruh produksi Di JawaTimur. Jurnal Ilmu Manajemendan Akuntansi Vol 5 nomor : 2tahun Desember 2017 (59)

Mehmet Saim Aşçı.(2016) Benefiting From The Collective Labor AgreementIn Turkish Collective BargainingSystem. Jurnal International Journal of Commerce and Finance, Vol. 2, Issue 2, 2016, 61-70.

Mittal, S., Dhar, R.L. (2015) Transformational leadership and employee creativity: Mediating role of creative self-efficacy and moderating role of knowledge sharing. Management Decision, 53 (5): pp. 894-910.

Maija, et al., (2017) Individual Innovation Competence: A Systematic Review and Future Research Agenda. International Journal of Higher Education, 6 (5): pp. 103-121.

Mahdi, Mohd Zin. (2012) The Relationship Between Job Satisfaction and Turnover Intention, American Journal of Applied Sciences, 9(9): pp. 1518-1526.

Mangkunegara (2015) Manajemen sumber daya manusia, Remaja rosdakarya offset-Bandung, ISBN 979-514-929-6.

Munir, R. I. S., Rahman, R. A., Malik, A. M. A., \& Ma'amor, H. (2012) Relationship between Transformational Leadership and Employees' Job Satisfaction among the Academic Staff. Procedia-Social and Behavioral Sciences, 65, pp: 885-890.

Rahadian Dimas Aninditiya, Arik Prasetya, Yuniadi Mayowan (2015) Pengaruh Perjanjian Kerja Dan Perjanjian Kerja Bersama Terhadap Hak-Hak Karyawan Dan Kepuasan Kerja. Jurnal Administrasi Bisnis Vol. 28 No. 1 November 2015.

Riny Chandra (2017) Pengaruh Lingkungan dan Kesejahteraan terhadap Etos Kerja Karyawan PTPN I Pulau Tiga di Aceh Tamiang. Jurnal Manajemen Dan keuangan,Vol.6, No.2, Nov 2017.

Dadang Heri Kusumah; Tri Wahyu Wirjawan; and Nurmubin Dalidjo. The influence of trade unions, collective labor agreements and industrial relations on the welfare of workers at 
Saeed, Asghar (2012) Examining the Relationship between Training, Motivation and Employees Job Performance - The Moderating Role of Person Job Fit. ISSN 2090-4304.Journal of Basic and Applied Scientific Research, 2(2): pp. 12177-12183.

Saeed, T., Almas, S., Anis-ul-Haq, M., Niazi, G.S.K. (2014), Leadership styles: Relationship with conflict management styles. International Journal of Conflict Management, 2 5(3): pp. 214-225.

Simmons, A. L., \& Sower, V. E. (2012) Leadership sagacity and its relationship with individual creative performance and innovation. European Journal of Innovation Management, 15(3): pp. 298 - 309.

Shin, S. J. \& Zhaou, J. (2003) Transformational leadership, conservation and creativity: evidence from Korea. Academic of Management Journal, 46(6): pp. 703-704.

Seda Kazmaci \& Aykut Ekiyor. (2015) The Impact of Innovative Service Attempts on Customer Loyalty in Health and Beauty Centers. International Journal of Economics, Commerce and Management, 3 (4) : pp. 1-14

Sugiyono. (2016) Metodologi Penelitian Kuantitatif, Kualitatif, dan R\&D. Bandung: CV Alfabeta.

Dadang Heri Kusumah; Tri Wahyu Wirjawan; and Nurmubin Dalidjo. The influence of trade unions, collective labor agreements and industrial relations on the welfare of workers at 